\title{
Percent Predicted Tidal Volume
}

National Cancer Institute

\section{Source}

National Cancer Institute. Percent Predicted Tidal Volume. NCI Thesaurus. Code C112387.

The volume of air moved into and out of the lungs during breathing at rest as a proportion of the predicted normal value. (CDISC) 